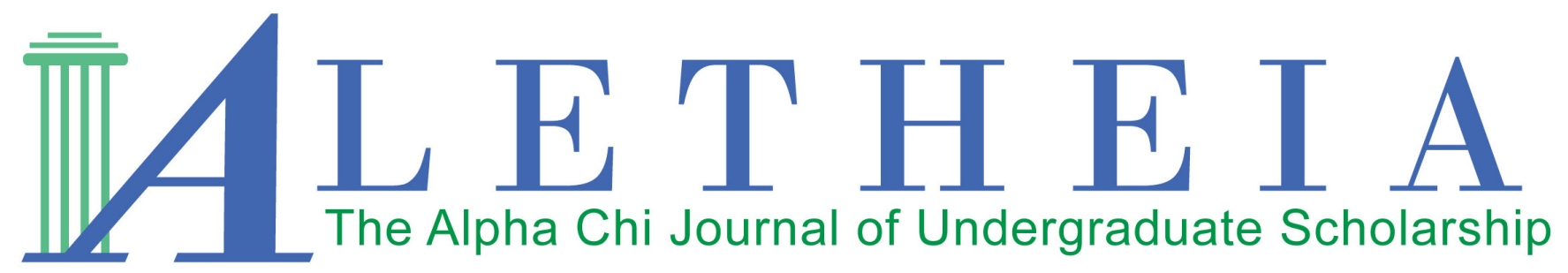

Volume 2 | Issue 2 | 2017

\title{
"What no other man can ever know": Foreshadowing a Modernist Self in Heart of Darkness
}

\author{
Sierra Bailey
}

\author{
Wayland Baptist University \\ Texas Alpha Eta Chapter
}

Vol. 2(2), 2017

Article Title: "What no other man can ever know": Foreshadowing a Modernist Self in Heart of Darkness

DOI: $10.21081 / \mathrm{AX} 0112$

ISSN: 2381-800X

Key Words: modernism, fin de siècle, selfhood, narrative, displacement, Heart of Darkness This work is licensed under a Creative Commons Attribution 4.0 International License.

Author contact information is available from the Editor at editor@alphachihonor.org.

\section{Aletheia-The Alpha Chi Journal of Undergraduate Scholarship}

- This publication is an online, peer-reviewed, interdisciplinary undergraduate journal, whose mission is to promote high quality research and scholarship among undergraduates by showcasing exemplary work.

- Submissions can be in any basic or applied field of study, including the physical and life sciences, the social sciences, the humanities, education, engineering, and the arts.

- Publication in Aletheia will recognize students who excel academically and foster mentor/mentee relationships between faculty and students.

- In keeping with the strong tradition of student involvement in all levels of Alpha Chi, the journal will also provide a forum for students to become actively involved in the writing, peer review, and publication process.

- More information and instructions for authors is available under the publications tab at www.AlphaChiHonor.org. Questions to the editor may be directed to editor@alphachihonor.org.

\footnotetext{
Alpha Chi is a national college honor society that admits students from all academic disciplines, with membership limited to the top 10 percent of an institution's juniors, seniors, and graduate students. Invitation to membership comes only through an institutional chapter. A college seeking a chapter must grant baccalaureate degrees and be regionally accredited. Some 300 chapters, located in almost every state, induct approximately 12,000 members annually. Alpha Chi members have been "making scholarship effective for good" since 1922.
} 


\title{
"What no other man can ever know": Foreshadowing a Modernist Self in Heart of Darkness
}

\author{
Sierra Bailey \\ Wayland Baptist University \\ Texas Alpha Eta Chapter
}

\begin{abstract}
Published at the turn of the nineteenth century, Joseph Conrad's Heart of Darkness occupies a liminal space that explores early ideas of a modernist Self. Questioning established narrative truths that marked Victorian fiction, Heart of Darkness illuminates the unnamed, unsaid, and unexplained through the narrative ellipses that surround the narrator, Marlow, Kurtz, and the Intended. Such ellipses symbolize the overwhelming disillusionment - the inability to articulate a defined selfhood - that marked the fin de siècle and the collective apprehension of the unknown. Conrad further displaces a Victorian tellability of identity through narratological design, psychological (un)awareness, and physiological ambiguity, which foreshadows approaching modernism. As the reader interacts with this disillusioned abyss, vague representations and uncertain realities culminate in the fundamental question of modernity: can one truly define, represent, or know the Self through narrative? While some attempt to proffer an answer, Conrad's Heart of Darkness embraces, albeit with unnerving hesitation, the indefinite essence of modernity's selfhood and illuminates the heart of the fin de siècle.
\end{abstract}

Key words: modernism, fin de siècle, selfhood, narrative, displacement, Heart of Darkness

The narrative structure of Joseph Conrad's Heart of Darkness, written and published at the fin de siècle, loses itself amongst the established and the indefinite - the perceived truths and the unknown meanings that rest within the tale itself. In turn, Conrad's use of these narrative threads poses questions of tellability, emphasizing the importance of "untellable" experiences within narrative. Reviewing the influence that Conrad exerted on modern writers, Jeffery Meyers notes that his narrative "techniques and themes, his passionate concern with . . . the terrors of loneliness and consolation of the secret sharer-have profoundly appealed to the modern sensibility, which he helped to create" (186). Such concerns are certainly representative of Conrad's own displacement as an expat and of his own experiences in the Congo. However, one should note that this concern for the displacement of the Self in narrative structure plays more than a mere autobiographical role. It is an exploration of textual narrative structures that reflect British modernism - an era perhaps best exemplified by writers such as Virginia Woolf, T. S. Eliot, and James Joyce - and its representations of the Self and the tellability of subjective selfhoods. Here one finds a progression toward modernist storytelling techniques in which meaning is found not in words themselves but rather in the structure through which they are presented. Thus, by examining the narratological displacement and the resulting disillusionment of the story's nameless narrator, Marlow, Mr. Kurtz, and the Intended through narrative ellipses - those things that remain unnamed, unsaid, and 
unexplained - in Heart of Darkness, one uncovers Conrad's foreshadowing of modernist tellability and transcendence of Victorian narrative ideologies. This narratological structure consequently serves as a reaction to growing concerns of Victorian identity and ultimately forms a foundation emblematic of literary modernism.

The notion of an established truth - the idea that, at the end of a narrative, a clear declaration of moral or social truth will offer itself to the reader-weaves itself throughout the early development of the novel as an established literary form. Thus, by the rise of the Victorian novel, the appearance of or the desire for an established narrative truth finds itself a familiar fixture of the era. Offering a review of these narrative structures and the consequent reception of Victorian novels, Linda M. Shires articulates that classic Victorian realism often held "A hierarchy of discourses, in which truth accrues to the implied author, the narrator, and the reader" (65). Further, Victorian realism "relies on third-person omniscient narration. This type of narration tends to efface its status as discourse and promotes a sense of organic, coherent form. Realism privileges a reading focusing on a central character or several central characters. It stresses a model of coherence or consistency not only in its form but also in the construction of characters" (Shires 65). This ideology of realism - though it can explore the increasing subjectivity of selfhood-seeks to provide its readership with a clear progression and outcome of story. In its search for a settled narration "almost every Victorian novel has at its heart some crime that must be uncovered, some false identity that must be unmasked, some secret that must be revealed, or some clandestine plot that must be exposed" (David 13). Noting this range of established narrative arcs in Victorian novels, Shires further asserts that even when "the consistency or coherence of a character is challenged, through any number of disrupting desires or external events, the movement of the narrative usually reinstates order" (65). As such, Victorian literature provided its contemporary readers with stories that sought a cohesive narration, promoting and supporting the emergence of an established truth recognized by both the characters and reader alike, moving the aesthetics of Victorian tellability to rely upon a procession of events that proffered a satisfactory conclusion.

Conversely, one finds that Conrad's elusive meanings and enigmatic conclusions in Heart of Darkness deny the sensibilities of Victorian tales that sought to establish narrative clarity. Instead, there emerges ques- tions of the unknown and the unsaid, mirroring cultural concerns that surrounded the fin de siècle. Commenting on this transition of narrative techniques - from Victorian assertions to modernist ambiguities-Deirdre David recalls that late-Victorian readers "dislodged from religious certainty by scientific discovery, found consolation in a novelistic power that both resembled divine omniscience and accepted responsibility for creation" (3). Faced with rapid advances in industrialization and decentering ideas from works such as Charles Darwin's Origin of Species, the late nineteenth-century carried an increasing concern for and disillusionment with the tellability of the Self's experience. These narrative forms were incongruent with the fin de siècle- $\mathrm{a}$ transitional era where narrative structure lacked established foundations of objective tellability. Such uncertainly frames Conrad's work as liminal in both structure and theme. And within this liminal space-in essence, a bridge between tightly woven Victorian narratives and the experimental aestheticism of modernism — one finds a tale of the untellable. As such, the structure of Heart of Darkness "repeatedly announces a rupture between the new conventions of modernism and the conventions of Romance and realism and identifies a modern consciousness as the point of departure for a new aesthetic model" (Nayak 35). Furthermore, this narratological structure, "confounding all narrative certainty, dislodging the reader from a stable secure interpretive position from which to get a grip on events," strips narrator, character, and reader alike of an established ground from which one can extract a shared meaning or experience (David 10). Here rest the narrative ellipses, those textual gaps that indicate the unnamed, unsaid, and unexplained.

Exploring these textual and narrative ellipses, those many dashes and ellipses that characterize Heart of Darkness, one finds that silence replaces Victorian assertions of truth. Reviewing Conrad's fin de siècle liminality-his exploration of Victorian disillusionment and modernist ambiguities-Jeremy Hawthorn emphasizes the importance of narrative ellipses and notes that "the gaps in Conrad's work constitute an essential aspect of his modernism, encouraging 'the imagination of the reader' to become an active participant in the search for truth" (5). However, instead of providing readers with an established narrative truth, the text creates spaces of silence where contemporaneous readers were prompted to look beyond words, beyond those Victorian structures, to rec- 
ognize the immense expanse between words and experience. This displacement of text and narrative transcends mere stylistic choices, as this disillusionment with truth mirrors late-Victorian anxieties of what rested beyond the fin de siècle. Conrad's readers must then recognize and move beyond the limitations of words to continue this search for a narrative truth. Yet, this search remains incomplete as the text's elongated narrative ellipses conclude with Marlow's inability to reveal Kurtz's truth to the Intended: "But I couldn't. I could not tell her. It would have been too dark - too dark altogether...." (Conrad 2010). Like Marlow, the reader is aware that the Intended remains blinded to the reality of Kurtz's voice, a truth that remains displaced by narrative ellipses; and like the narrator, the reader is conscious of Marlow's disillusionment within his own tale. Noting that "readers may attribute narratological ellipses in a work of fiction to either the author, the narrator, or a character - or to any combination of these" the text entraps itself within its own ambiguities (Hawthorn 10). Only silence remains - a narrative ellipsis that exists between author, text, and reader, as the unnamed narrator concludes the tale without giving voice to a narrative truth.

Recognizing the search for the tellability of a tale's truth, the reader must turn to the emblematic "woman, draped and blind-folded, carrying a lighted torch" - perhaps a displaced representation of Kurtz's Intendedwho appears as an image of Victorian disillusionment (Conrad 1971). While this image stands as a beacon of European hope in a jungle of despair, the woman is unable to dispel the sinister shadow of modernity's reality as she serves to illuminate the very darkness from which the blindfold shields her. Asserting that the woman's displacement in the narrative of Conrad's work indicates the position he holds among modernist writers, Samir Elbarary argues that Kurtz's portrait of the unnamed torchbearer "could be said to suggest, among other things, the simplicity of the ideal and the complexity of reality, the illusion of light and the truth of darkness" (119). Alongside Marlow, the reader recognizes that the light of truth does not always illuminate the truth that also rests within the darkness, just as established Victorian narrative truths would not define the narrative of the fin de siècle.

As such, the Intended's Victorian rectitude of mourning is overshadowed and emphasized by her disillusioned understanding of Kurtz's identity. This is best seen when she first states that "his goodness shone in ev- ery act" before acknowledging that "he died as he lived" (Conrad 2009). Here, the reader must recognize the subjectivity of the Self, as the Intended's offered truth of Kurtz merely emphasizes the horrific unknown aspect of his life. The dissonance of these two perspectives, that of the Victorian emblem and that of Marlow's blurred experience displaced by the unnamed narrator, is a striking narrative ellipsis that the reader cannot avoid; the unknown and unsaid substance of Kurtz's horror continues to echo throughout the text. Although the Intended's search for a narrative truth leads her to the conclusion that "it is impossible that all this should be lost- that such a life should be sacrificed to leave nothing - but sorrow .... something must remain" and that "[Kurtz's] words at least have not died," the reader experiences the same disillusionment emanating from Marlow's shaken selfhood because Kurtz's true self remains shrouded in silence (Conrad 2009). Further illuminating the Intended's displaced state in this darkness, Marlow exclaims: "I [spoke] with ... despair in my heart ... . bowing my head before .... the great and saving illusion that shone with an unearthly glow in the darkness ... from which I could not have defended her-from which I could not even defend myself" (Conrad 2008). Here one finds reference to Kurtz's painting, the woman bearing light to the darkness. A symbol of the Victorian era, the Intended offers the reader a shadow of a narrative truth - the mystery of Kurtz concludes with her memory. Yet, the narrative ellipses remain as Marlow continues to hear the echoing voice. Despite the Intended's disillusioned belief that Kurtz was both man and voice, she will inevitably encounter the darkness - a disillusioned view of established narrative truths - that Victorian literature brought upon itself. Similarly, Marlow knows he cannot deny the reality that rests within the horror of Kurtz's last words, which forces the reader into the unnamed void that is "too dark - too dark altogether" (Conrad 2010). This continued inability to articulate the truth that both the Intended and Marlow wish to find signals an increasing apprehension for a liminal era, the fin de siècle, that remained shrouded in uncertainty, requiring readers to search for a narrative truth beyond the surface text.

The displacement of text, marked by spaces of silence and narrative ellipses, is further exemplified through the duality of narrative perspective. Indeed, the (dis)placement of Conrad's unnamed narrator is perhaps the most bewildering element of within Heart of Darkness - an enigma that signals narratological significance. 
When one first encounters the story, it is easy to overlook the validity of the ambiguous Self, the unnamed narrator, and to forget that Marlow is not the true teller-of-tales. However, when one approaches the text with a narratological mindset, one sees that its story is enveloped with quotation marks. True narrative authority, complicating the tellability of the tale, is found only in the ellipsesthe brief moments when Marlow ceases to speak and the unknown narrator emerges to insist the following:

The yarns of seamen have a direct simplicity, the whole meaning of which lies within the shell of a cracked nut. But Marlow was not typical ... to him the meaning of an episode was not inside a kernal but outside, enveloping the tale which brought it out only as a glow brings out a haze, in the likeness of one of those misty halos that sometimes are made visible by the spectral illumination of moonshine. (Conrad 1956)

Here one finds a recognition of and a reaction to narrative structures emblematic of fin de siècle concerns. Certainly, the "direct simplicity" expected of Marlow's wild tale acknowledges the presence of established narrative forms. Yet, the narrator's emphasis of the "misty halos" seems to appear as a precursor to modernist concerns of tellability that sought to explore the immense subjectivity of the Self. As the narrator further comments, "we knew we were fated ... to hear about one of Marlow's inconclusive experiences" (Conrad 1958). Thus, with each new set of quotation marks, one recalls that the tellability of Marlow's story is removed from experience itself through the tale's narrative form - the true narrator cannot truly relate the sensations of the story.

Moreover, as Vincent Pecora notes in his article, "Heart of Darkness and the Phenomenology of Voice," the use of quotation marks to displace the narrator from Marlow also displaces the readers from the text, which forces them to "become conscious of [their] own suspicion of personal identity, and of the spoken word as a sign of presence" (999). Though Marlow desires to provide a comprehensible tale, the quotation marks remove the readers from an experience of the Self-a narrative structure that isolates the unnamed narrator from Marlow, and the reader from the tale's own narration. This marks the structure of Heart of Darkness, like Conrad's Nostromo, as an "imaginatively dangerous activity, entailing a loss of self in the world imagined" (David 8). This question of identity and presence leads the reader to an abyss of disillusionment in which the seaman's story transcends the ability, emblematic of Victorian narrative structures, to arrive at a tale's conclusion based on a stated moral truth. Furthermore, Bruce Teets argues that Conrad creates a "a radical disorientation in his works, an obliteration of any stable relation between the self and the world; and this fact raises the question of whether there is a world to which the self belongs" (375). This refusal to provide readers with an established narrative transforms the text's intentions and representations of the Self into the ineffable. While Marlow merely speaks of a nightmarish story, the unnamed narrator reflects an uncertainty which mirrors the ambiguity emblematic of modernist works and the narratological explorations occurring at the fin de siècle.

Having moved toward the realms of narrative disillusionment, one finds that Marlow's jungle story is synonymous with the journey toward a modernist Self-memory transforms into experience, while experience becomes a haze that is "in the likeness of one of these misty halos that sometimes are made visible by the spectral illumination of moonshine" (Conrad 1956). Commenting on the creation of a blurred experience in narrative, Walter Pater, a Victorian essayist and literary critic, articulates the inability to reconcile one's truth with another's:

Experience, already reduced to a group of impressions, is ringed round for each one of us by that thick wall of personality through which no real voice has ever pierced on its way to us, or from us to that which we can only conjecture to be without. Every one of those impressions is the impression of the individual in his isolation, each mind keeping as a solitary prisoner its own dream of the world. (187-188)

This shadow of doubt, evident but suppressed in Victorian literature, transforms into the fin de siècle concern for and disillusionment with representations of the Self, embodied by the narratological structure of Heart of Darkness. Thus, the text's "misty halo," an effect created by narrative ellipses, obscures Marlow's attempts to reveal the truth and the meaning of his own experiences. 
Such is evident in his frustrated outburst of "No, it is impossible; it is impossible to convey the life-sensation of any given epoch of one's existence, - that which makes its truth, its meaning - its subtle and penetrating essence. It is impossible. We live, as we dream - alone ...." (Conrad 1973). The possibility of a shared truth is denounced while the Self is set adrift in a sea of disillusioned thought.

Marlow, a sailor of these tumultuous waters, is displaced within his nightmare of choice in which his inability to explain or relate an experience of the Self leads to a state of distended liminality within the text. Though he speaks, Marlow's words fail to provide an objective truth and he is instead faced with the isolation of a narrator enclosed within narrative ellipses. In his article, "Obscurity, Apophasis, and the Critical Imagination: The Unsayable in Heart of Darkness," Stephen Skinner further articulates this phenomenon:

The limits of words, together with the shadowy edges of perception and understanding, are of course frequent concerns in Conrad's work and are indicative of his modernism. His stories often represent and suggest more than they say: the unsaid of dialogue and narrative hints at layers of meaning beyond what is read, and Conrad's explicit and implicit insistence on mysteries beyond words emphasize the unsayable. (94)

Indeed, Marlow's displacement within the text and disillusionment of experience and memory seem to anticipate the fin de siècle fear that "behind all the phenomena perceptible to human senses there might lie-nothing," that those things which remain unnamed, unsaid, and unexplained might be nothing more than the blank void of one's soul or a lack thereof (Lester 31). Facing the fin de siècle, the narrative ellipses of the text displace memory and experience and replace them with an anxiety of having to converse with the unknown.

Upon further examination one finds that this fear of encountering the untellable, those silent spaces within the text, emphasizes Mr. Kurtz's displaced role as a voice in the darkness - a voice which serves as a distorted embodiment of modernity's void. When readers are introduced to this enigma of a character, they are told that he was a man who "presented himself as a voice" (Conrad 1988). Indeed, when Marlow first encounters the idea of Kurtz, he declares: "[Kurtz] was just a word for me" - a statement that seems to reflect Marlow's own acknowledged fear of the unknown (Conrad 1973). Yet, this reality of an unknown state of being distends Kurtz's voice above the text and transcends Victorian reliance upon the existence of a narrative founded on an established moral truth. When the voice of Kurtz, a man supposed to be a "very remarkable person," presents him as a man who "lacked restraint in the gratification of his various lusts" and who had "something wanting in him," the reader's disillusionment with truth leads the reader to the same unexplainable void Marlow continues to face (Conrad 1966; 1995). Thus, this desire to understand the meaning, the narrative truth, behind the displaced voice is reminiscent of the Victorian desire to maintain an established narrative truth.

Heart of Darkness, however, is unable to offer the reader such a solution because the fin de siècle indicated that "the moment of ultimate doubt had arrived" and that "the world of 'truth' had become shadowy and fluctuating at best; man's ability to perceive it had diminished toward the vanishing point" (Lester 37). This anxiety of stepping into and encountering the unknown presents itself in Conrad's text through what remains unsaid. This is mirrored in Marlow's own outburst of despair when Kurtz's voice remains a displaced essence to the narrator and reader:

Do you see him? Do you see the story? Do you see anything? It seems to me I am trying to tell you a dream - making a vain attempt, because no relation of a dream can covey the dream-sensation, that commingling of absurdity, surprise, and bewilderment in a tremor of struggling revolt, that notion of being captured by the incredible which is of the very essence of dreams .... . (Conrad 1973)

Just as the narrative ellipses within the text prevent the reader from understanding the unknown of this dream-like experience, Marlow's encounter with the voice cannot explain the nightmarish void he must confront. As the narrative structure falls into obscurity, marked by the reader's inability to experience Marlow's nightmare, the unnamed narrator interjects to assert that Marlow "was silent for awhile" and that "for a long time already he, sitting apart, had been no more to us than a voice" (Conrad 1973). Such a declaration further impacts the narrative's tellability, as Marlow also transforms into a disembodied voice. 
This narratological structure, as Conradian scholar Michael Greaney notes in his book Conrad, Language, and Narrative, creates "an echo chamber of decentered voices in search of an origin" (69). This echo of distorted voices is best seen in Marlow's cries of "A voice. He was very little more than a voice. And I heard-himit - this voice - other voices - all of them were so little more than voices - and the memory of that time itself lingers around me, impalpable, like a dying vibration of one immense jabber" (Conrad 1988). Encased in quotation marks, this declaration is indicative of the elusive substance of the tale itself-Marlow's story of voices is carried forward by his own disembodied voice, which is further related by a narrator who remains displaced from the text. Thus, one finds that "Marlow's narrative seems to be on the edge of a modernist 'turn inward' towards a non-material identity" (Srila Nayak 32). Indeed, breaking free of physical constraints, Kurtz and his declared greatness, like Victorian narrative ideologies, passes into oblivion, leaving Marlow to face the unknown: "There was nothing either above or below him, and I knew it. He had kicked himself loose of the earth. Confound the man! He had kicked the very earth to pieces. He was alone, and I before him did not know whether I stood on the ground or floated in the air. . . . Soul! If anybody had ever struggled with a soul. I am the man" (Conrad 2002). As such, Marlow's own disillusionment with the Self, marked by his inability to "know," further displaces Kurtz's voice; he cannot accept the nothingness of Kurtz's being, as it would require him to accept his own intrinsic emptiness. This emptiness, emphasized through the unnamed narrator's assertion that Marlow too is merely a voice lost within narrative ellipses, further signals the radical fin de siècle subjectivity of Conrad's narrative structure.

Thus, as Marlow continues his journey toward the heart of darkness through narrative ellipses, perhaps emblematic of the unmarked years of the fin de siècle, he begins "the self's downward journey into its own unconsciousness" where narrative truths transcend expected declarations and transform into a shadow that leaves the reader lost in the residual darkness of Marlow's voice (Elbarary 121). This shadow serves as the liminal space between late-Victorian tellability and fin de siècle narratives, between those things which can be declared and those which linger in their own state of undetermined selfhood. While Marlow faces the void that lies within Kurtz's elliptical declaration of "The horror! The hor- ror!" and examines the dying man as one would "peer down at a man who is lying at the bottom of a precipice where the sun never shines," Marlow must also greet the coming age of a modernist selfhood - an era of things unnamed, unsaid, and unexplained (Conrad 2004). It is in this moment that Marlow transcends the divide between life and death and attempts to "step over the threshold of the invisible," and as Fred Solinger asserts, "it is from that threshold, that liminal position [from which] Marlow communicates" (Conrad 2005; 69). Once again, the reader is displaced outside of reliable revelations of Victorian narrative truths. The reader's own disillusionment no longer merely emanates from the abrasive quotation marks of an unnamed narrator; disbelief rests in the fact that 'Kurtz's voice, [is] now internalized and preserved as an echo in Marlow's consciousness - as if somehow it has replaced the echo of the self that Marlow feels unable to produce on his own" (Pecora 1008). As the sound of such a foreboding echo haunts the text, the unspoken implications of "The horror! The horror!" solidify Marlow's undetermined identity in a modernist selfhood (Conrad 2004).

Consequently, the text's various narrative ellipsesthose moments in which narrative structure transcends the tellability of a tale's truths and instead obscures meaning in silence and ambiguity_-indicate a position of displacement and disillusionment that reflects an inability to reconcile modernity's abstractions of the Self with Victorian narrative ideologies. Bridging these Victorian and modernist concerns, Heart of Darkness occupies a liminal space where "a denial of conclusiveness, a negation of narrative certainty, and an overriding sense that what matters cannot be said" leaves the reader facing a space in which "the familiar [Victorian narrative] has become unfamiliar [modernist narrative]" (Skinner 102; Lipka 33). As Marlow is displaced by the unnamed narrator's unsettling quotation marks, the reader begins to realize that nothing is as it seems, that narrative cannot provide a satisfactory shared experience. While Marlow attempts to expound on the sensations of his experience in the Congo, a haze descends on one's ability to see into the nightmare of this perceived reality. However, one encounters one's own nightmare when the unknown reality behind Kurtz's voicing of a horrific void removes one's ability to settle an absolute truth of experience in anything but an abyss of disillusionmentfiction and reality are overshadowed by the blurred representations of the Self. Even the Intended, whose role 
as the blindfolded woman is to offer light, illuminates a "heart of an immense darkness" (Conrad 2010). As these moments deny Victorian narrative techniques, they further allow Conrad to indicate the struggles of the emerging modernist Self - the unnamed, unsaid, and unexplained existence that one would encounter at the dawning of the twentieth century and would later be explored through literary modernism. In essence, Heart of Darkness serves as an attempt to reconcile late-Victorian disillusionment of the known and unknown with the understanding that a new era would be "[one's] own reality-for [oneself], not for others," a chance to explore and experience "what no man can ever know" (Conrad 1974).

\section{Works Cited}

Conrad, Joseph. "Heart of Darkness." The Longman Anthology of British Literature: The Twentieth Century and Beyond, edited by Kevin. J. H. Dettmar, $4^{\text {th }}$ edition, Pearson, 2010, pp. 1954-2010.

David, Deirdre. "Introduction." The Cambridge Companion to The Victorian Novel, Cambridge UP, 2001, pp. 1-16.

Elbarbary, Samir. "'Heart of Darkness' and Late-Victorian Fascination with the Primitive and the Double." Twentieth Century Literature, vol. 39, no. 1, 1993, pp. 113-128.

Greaney, Michael. Conrad, Language, and Narrative. Cambridge UP. 2002.

Hawthorn, Jeremy. "'No need of words': Joseph Conrad's Use of the Typographical Ellipsis in Under Western Eyes and "The Secret Sharer" Conradiana, vol. 43, no. 2-3, 2011, pp. 5-23.

Lester, John A. Jr. Journey Through Despair 1880-1914: Transformations in British Literary Culture. Princeton UP, 1968.

Lipka, Jennifer. “'The horror! The horror!': Joseph Conrad's 'Heart of Darkness' as a Gothic Novel." Conradiana, vol. 40, no. 1, 2008, pp. 26-37.

Meyers, Jeffrey. "Conrad's Influence on Modern Writers." Twentieth Century Literature, vol. 36, no. 2, 1990, pp. 186-206.

Nayak, Srila. "Two Narratives of Modernism in Heart of Darkness." Conradiana, vol. 44, no.1, 2012, pp. 29-49. https://doi.org/10.1353/cnd.2012.0004

Pater, Walter. The Renaissance: Studies in Art and Poetry. University of California Press, 1873.

Pecora, Vincent. “'Heart of Darkness' and the Phenomeno ogy of Voice." English Literary History, vol. 52, no. 4, 1985, pp. 993-1015.
Shires, Linda M. "The Aesthetics of the Victorian Novel: Form, Subjectivity, and Ideology." The Cambridge Companion to The Victorian Novel, edited by Deirdre David, Cambridge UP, 2001, pp. 61-76.

Skinner, Stephen. "Obscurity, Apophasis, and the Critical Imagination: The Unsayable in "Heart of Darkness." Conradiana, vol. 42, no. 1, 2010, pp. 93-106.

Solinger, Fred. “'Absurd be - exploded!': Re-Membering Experience through Liminality in Conrad's 'Heart of Darkness." Conradiana, vol. 40, no. 1, 2008, pp. 61-70. Teets, Bruce. "Modernism, Conrad \& Co." English Literature in Transition, 1880-1920, vol. 35, no. 3, 1992, pp. 374- 378. 